\title{
The Relationship between the Leadership Styles of Lebanese Public School Principals and Their Attitudes towards ICT versus the Level of ICT Use by Their Teachers
}

\author{
Norma Ghamrawi \\ Faculty of Education, Lebanese University, Beirut, Lebanon \\ Email:nghamrawi@ul.edu.lb \\ Received November $13^{\text {th }}$, 2012; revised December $15^{\text {th }}$, 2012; accepted January $4^{\text {th }}$, 2013
}

\begin{abstract}
This study investigates the relationship between the leadership styles exhibited by almost $50 \%$ of the total population of public school principals $(\mathrm{N}=651)$ in Lebanon and their attitudes and the level of use of technology for educational purposes in their schools. Data were collected by surveying school principals via two questionnaires. Moreover, one teacher from each participant public school $(\mathrm{N}=651)$ completed a questionnaire pertaining to the level of use of technology in the school. Findings suggest the existence of positive correlation between the autocratic leadership styles of school principals and their negative attitudes towards the use of ICT for educational purposes. In addition, the results of the study accentuate another positive correlation existing between principals' attitudes towards the use of ICT for educational purposes and the level of its use by their teachers in schools. Recommendations for further research and implications for school leadership and training programs are provided.
\end{abstract}

Keywords: Leadership Styles; School Management; ICT; School Improvement

\section{Introduction}

Within the framework of the 21st century schools, Information and Communication Technology (ICT) has been viewed as a tool that has the potential to empower teachers and learners, promote change and foster the development skills needed to face the challenges confronting schools (Ghamrawi, 2010). It is even argued that schools may not claim that they are equipping students with the 21st century skills unless they migrate from traditional teaching and learning settings into settings where the use of technology is well incorporated (Yelland, 2001). This is parallel to Grimus (2000) and Bransford et al. (2000) who consider ICT in schooling as a guarantee for the future of student education. Moore and Kearsley (1996) and Young (2002) emphasized the importance of technology-facilitated educational programs as being tools which enable learners to learn anytime and anywhere.

However, the promotion of ICT in schools entails an active role to be taken by the school principal according to the international literature of ICT (Ghamrawi, 2010; BECTA, 2003; Haynes, 2007; Kearney \& McGarr, 2009; Kirkland \& Sutch, 2009). Although infrastructure is important, leadership is the critical element in establishing technology as a part of school culture (Anderson \& Dexter 2000). This is further asserted by the manifestation of the British Office for Standards in Education (Ofsted) (2000) that considered all efforts of school improvement to be susceptible to failure in the absence of bold leadership in the school. In fact, studies from several parts of the world have stipulated a strong message pertaining to the imperative role played by school leaders in steering change, and hence providing vision and objectives for using ICT in schools (Yee, 2000; Yuen, Law \& Wong, 2005; Schoeny, 2002; Schiller, 2002).
Despite the fact that several studies across the globe have delved into investigating leadership matters in relation to ICT in schools (MacDonald, 2006); none has been conducted within the Lebanese Public School setting. This paper seeks to explore the relationship existing between the leadership styles exhibited by public school principals in Lebanon and their attitudes towards ICT use for educational purposes and the level of use of it by teachers in their schools. It is hoped that the findings of this study would be beneficial for the development of training programs, which aim at rendering public school leaders advocates of ICT in schools.

\section{Purpose of the Study}

The purpose of this study was to investigate the relationship existing between the leadership styles of school principals and the attitudes they hold towards technology. In addition, the study shed light on the level of use of ICT by teachers in relation to such styles and attitudes.

Though many studies have addressed the impact of leadership on ICT integration in education, as well as teachers' attitudes and the level of use of technology; none of these have addressed the trio relationship: leadership styles, attitudes of leaders and level of use of ICT in schools (represented in Figure 1). Moreover, no earlier studies have been conducted in Lebanese Public Schools addressing any of these issues.

The research questions addressed in this study are as follows:

1) What are the leadership styles that prevail in Lebanese Public Schools?

2) What are the attitudes among principals towards the use of ICT for educational purposes?

3) What is the level of ICT use for educational purposes by teachers? 


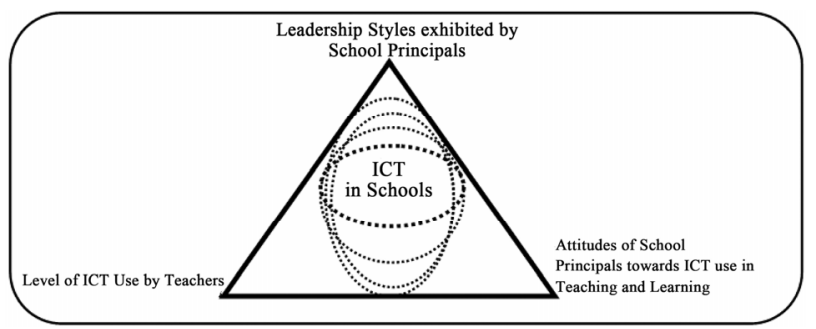

Figure 1.

Scope of the study.

4) Is there a significant relationship between level of use of ICT by teachers and principals' attitudes towards ICT?

5) Is there a significant relationship between the leadership styles of Lebanese Public School Principals and their attitudes towards the use of ICT for educational purposes?

\section{Review of Literature}

\section{Information and Communication Technology (ICT) in Education}

There are opposing views to the impact ICT has on the acquisition of learning by students. On one hand, ICT has been viewed as a tool for promoting quality learning. This is supported by studies from several parts of the globe such as Ghamrawi (2011), Gillespie (2006), Romeo (2006), Murphy (2006), Wong et al. (2006), Becta (2003), Yelland (2001), Oliver (2000) and Grimus (2000).

Grimus (2000) assures that “...by teaching ICT skills in primary schools the pupils are prepared to face future developments based on proper understanding” (p. 362). This is also manifested by Yelland (2001) who emphasizes the fact that there is no efficient and effective schooling unless ICT is well integrated within teaching and learning.

Oliver (2000) explains that, when employed effectively in education, ICTs have the potential to support competency and performance-based curricula. This is possible by virtue of the potential of ICT to provide unlimited access to resources made available from all over the globe. With this made available, students' literacy would be strongly enhanced (McCausland et al., 1999) as they will be urged to locate the information they are seeking and hence would get to learn how to fish for their knowledge rather than receiving information boxed in textbooks. Thus generic student skills would expand. Reeves \& Jonassen (1996) make a similar point yet go beyond that assuring that ICTs are potential tools that guarantee student-centered learning. In other words, ICT in education could serve as a powerful tool for constructivism whereby students learn through actively constructing their own knowledge. Kulik's (1994) study showed that students who were exposed to ICTs learned more in less time as opposed to their peers who did not. Moreover, this study has shown that students enjoyed their classes much more than their peers who were not given to use ICT in their learning.

Advocates of ICT in education assure that ICT in education has the potential not only to secure rich learning environments but go beyond that to claim that they impact student achievement.

"ICT has the potential to promote higher-order thinking skills... It has the potential to a) engage students in au- thentic learning contexts; b) offer for students a rich, effective and efficient learning environment which improves their performance and learning; and c) impact student achievement positively” (Ghamrawi, 2011: p. 17).

In fact, the study conducted by Kulik's (1994) revealed that, on average, students who used ICT-based instruction scored higher than students who did receive ICT-based learning opportunities. This is in line with a study conducted by Attwell and Battle (1999) who examined the impact of the availability of computers at student homes versus how well they did at school. The study that included 64,300 students assured a strong correlation between the use of technology and student performance.

Parallel to this, Sosin et al. (2004) assure that some ICT tools do possess some impact on student achievement, yet some other tools do not. In other words, the selectivity of the tools that best suit a given context is a premise to ensure positive impact on student learning (Ghamrawi, 2011). A study conducted by Fuchs and Woessman (2004) using data derived from the Programme for International Student Assessment (PISA) revealed strong correlation between the availability of ICT in schools and students' performance in general. However, this same study alerts to the fact that other resources available in schools could impact achievement as well.

For this reason, at the other end of the continuum, opponents of the use of ICT in education claim that ICT has no impact on student learning and student achievement. Leuven et al. (2004) explain that there is a consistently negative and marginal relationship between ICT use and some student achievement measures. Coates et al. (2004) explain through his study that students who were enrolled in face-to-face courses did significantly better than their peers who received their learning through on-line courses.

ICT can be misused by students where they could use it in order to expand their spare time by decreasing the time they often allocate to studying (Leuven et al., 2004). Glennan and Melmed (1995) make a point in this line assuring that Technology use should be coupled with a well-knit strategic plan for reforming education. If this is not the case, the authors argue that Technology use will have no impact on student learning and achievement. Students need to enjoy several skills in order to be able to really make advantage of ICT (Kay \& Honey, 2005). They need to be able to crunch, compare and choose necessary data among the glut of data available in electronic formats. Finally, Postman (2005) argues that ICT have strong potential to teach both content and skills, yet it fails at teaching values to students.

Despite the various arguments about ICT, there is no doubt that technology is invading all life aspects including education. Whether we are opt to use it in formal education or not, it is evident that students are using it extensively throughout the day where they learn informally (Ghamrawi, 2011). If used well, "Blogs, Wikis, Face Book, Twitter, or other social networking sites, which students use for chatting and enjoy the majority of their time with, may be powerful tools for learning" (Ghamrawi, 2011: p. 11). At this point, it is important to shed light on the role played by school leadership in creating the culture and setting the vision conducive to the appropriate integration of ICT in education.

\section{Leadership Styles of School Principals}

Google reports 440,000,000 hits under the title "school lead- 
ership" as opposed to 365,000,000 hits for the title "school management" (search being conducted on September 27, 2012). In fact, the migration from management to leadership in schools has been considered a decisive factor in shielding any reform endeavors (Ofsted, 2000). Through management, principals facilitate the work of school by ensuring that what is done is in accord with the organization's rules and regulations. While through leadership, principals ensure that the work of the organization is what it needs to be. Bennis and Nanus (1985) put it this way: "Managers are people who do things right and leaders are people who do the right thing” (Bennis \& Nanus, 1985: p. 21).

School leaders enjoy a set of characteristics that makes their teachers work towards desired goals. Day et al. (2009) emphasize eight characteristics presented in Figure 2.

The below characteristics suggest that school leaders need to be instructional leaders who are knowledgeable enough about matters that relate to teaching and learning and the overarching curriculum; besides building and nourishing teams in schools. Yet above all, those leaders need to be able to set the vision that would secure stewardship overall improvement initiatives.

Principals often lead their schools in various ways; these ways are called styles of leadership. For example, in setting the vision, one principal may involve all teachers in the schools in setting that vision. Through this, the school principal would be exhibiting democratic/participative leadership. However, another principal may set the vision by him/herself and then impose it on the school community. This is a principal who embraces an autocratic/directive leadership style. A third principal may ask teachers to sit together and set that vision without being involved at all in the process. That principal would be practicing delegative/non-directive leadership. In other words, leadership style of a school principal is an expression of how that principal manages the work flow, addresses human resources, and the level to which they allow others to contribute to decision-making and problem solving (Goleman, 2004). It basically refers to the distinctive behavior in which an individual leads others. Other nomenclature for leadership styles also appears in the literature such as "authoritative", "laissez-faire", "affiliative”, "coaching”, “coercive”, "commanding”, "visionary”, "pacesetting” leadership styles, etc... which can fit into the above three categories in one way or another.

Through the autocratic leadership style, principals maintain full authority and control over all school aspects. They practice close scrutiny and control over teachers. Teachers led by autocratic principals often feel not trusted, demoralized and unmotivated (Ghamrawi, 2006). While through democratic/participative leadership style, school community is allowed to partici-

\begin{tabular}{|l|l|l|}
\hline $\begin{array}{l}\text { Build relationships outside school } \\
\text { community }\end{array}$ & Define their values and vision \\
\hline $\begin{array}{l}\text { Build collaboration } \\
\text { internally }\end{array}$ & $\begin{array}{l}\text { Dimensions of } \\
\text { Successful } \\
\text { Leadership }\end{array}$ & $\begin{array}{l}\text { Reshape conditions for } \\
\text { teaching and learning }\end{array}$ \\
$\begin{array}{l}\text { Enhance quality of } \\
\text { teaching and learning }\end{array}$ & Restructure and redesign \\
\hline Enhance teacher quality & \multicolumn{3}{|c|}{ Enrich the curriculum } \\
\hline
\end{tabular}

\section{Figure 2}

Day et al. (2010) 10 strong claims about effective school leadership. Nottingham: National College for Leadership of Schools and Children's Services. pate in decision-making and problem-solving. The principal acts as a coach who takes the final decision but after checking the views of staff members. Teachers who are led by democratic leaders enjoy the trust invested in them and hence pay it back through cooperation and team spirit (Goleman, 2000). Finally, non-directive leaders give full freedom to staff members with very little or no input. They do not provide any focus or direction. Though this kind of leadership style work well with experienced staff, still the general notion about such a leadership style is that it renders school climate into an insecure one where "survival of the fittest" mode dominates (Goleman, 2000).

Although democratic leadership styles have proven to be mostly productive in school administration, it should be noted that there is nothing so called "best leadership style". Every context and even every situation requires a specific leadership style to be exhibited by the principal (Goleman, 2000). Within the business domain, "leaders who have mastered four or more, especially the authoritative, democratic, affiliative, and coaching styles, have the best climate and business performance" (Goleman, p. 11).

\section{Leadership and ICT}

A huge body of literature argues that school leaders play an imperative role in terms of setting the stage for the effective integration of ICT in schools (Kearney \& McGarr, 2009; Kirkland \& Sutch, 2009; Haynes, 2007; Steed et al., 2005; Jacobson \& Hunter 2004; Schiller 2003; Solwinski, 2000). Condie and Munro (2007) who enlist a large number of barriers against the effective integration of ICT in schools, assure that school leadership tops this list. Sweeney (2005) assures that "effective leadership is the most critical component in ensuring the successful implementation of any program in an educational setting” (p. 48).

Leadership has been considered as the basic tool for the creation of the vision that acts as a driving force for ICT integration in schools (Otto \& Albion, 2002). It has the potential to secure teacher commitment as to the improvement of teaching and learning practices inside the classroom using it (Hayes, 2007). “...leaders must be able to articulate an institutional / organizational vision that assumes widespread access to information and services via networks” (Katz, 2002: p. 52). The Organization for Economic Co-operation and Development (OECD) converges to this same point by assuming that "Visionary school leadership is needed to bring about and sustain the dramatic changes enabled by ICT, to persuade and give confidence to all involved...” (OECD, 2001: p. 16). Moreover, school leaders create the culture that safeguards ICT initiatives within the school (Kirkland \& Stutch, 2007). Studies show that when school leaders are pedagogical leaders, they exhibit a greater influence on shaping how well ICT impacts student learning (Kearney \& McGarr, 2009).

In most studies about leadership and ICT, the practical knowledge and skills of school leaders are emphasized as means to ensure ICT integration (Flanagan \& Jacobsen, 2003). In fact, it is considered as a prime for advocating ICTs in schools. The ability of school principals to plan effectively has also been highlighted in the literature (Hayes, 2007). Other leadership considerations appear in the literature include budgeting, staffing, resourcing and securing effective teacher training besides managing infrastructures (Anderson \& Dexter, 
2000).

Gaffney and Schiller (2001) and Yee (2001) each suggest a list of characteristics essential for effective ICT leaders. Table 1 compares the two lists.

The common ethos that joins both lists is the fact school leaders should not exhibit only managerial skills; they should also demonstrate leadership skills. So the school principal should be a manager who is "capable of planning and budgeting, organizing and staffing, controlling and problem solving, and producing a degree of predictability" (Caldwell, 2007: p. 225). At the same time, the school principal should act as a catalyst of change "establishing direction, aligning people, motivating and inspiring, and achieving change" (Caldwell, 2007).

Though studies do underscore the role played by school principals in terms of leading change towards integrating ICTs in schools, only few studies detail leadership attributes auspicious for that. Fullan (2005) considers distributed leadership as a prime for successful ICT integration in schools. Through distributed leadership, responsibility is shared across the school.

Spillane (2009) illustrates that a distributed leadership frame-

Table 1.

Characteristics of effective ICT school leaders.

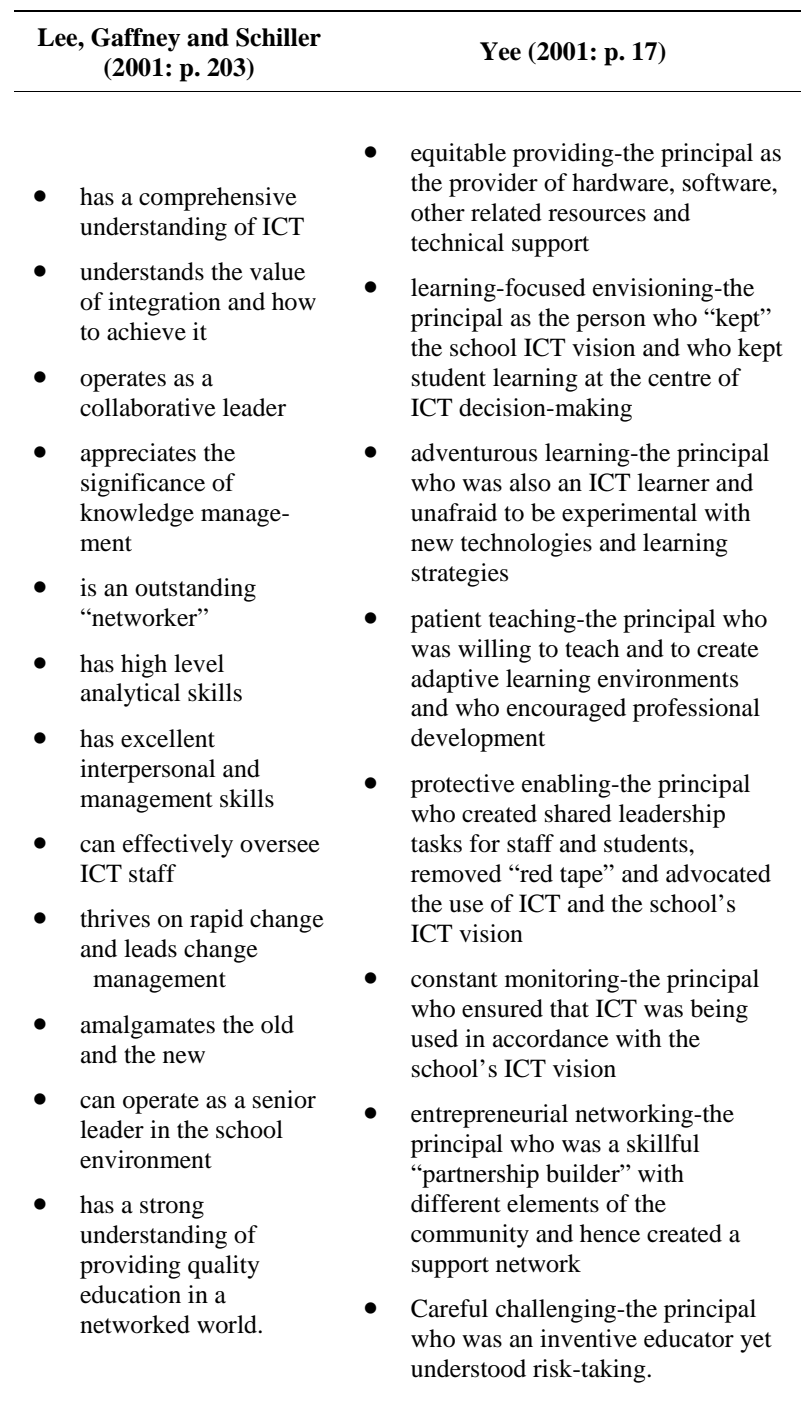

work involved “.... a cast of others, ....such as assistant principals, curriculum specialists, mentor teachers, and department chairs (p. 71). Kirkland and Stutch (2007) explain that distributed leadership secures a shared responsibility for innovation. That is to say, with the involvement of teachers in the ICT planning process, there would be more chances for success (Kozma, 2003).

The literature assures that through transformational leadership, chances for success with ICT integration are ample (Day, 2003). A transformational leader is people centered (Day, 2003); a role model for the school community (Harris, 2003) and secures a shared school vision (Dubrin et al., 2006). However, the literature does not provide details as to the leadership styles that best support ICT initiatives particularly in K-12 education.

\section{Attitudes and Level of Use of ICT in Schools}

Studies addressing ICT integration in the teaching and learning process have underscored also teachers' attitudes towards ICT (Albirini, 2006). Kluever et al. (1994) consider attitudes as a key factor determining whether teachers would tend to accept computers as teaching tools that they would employ in their teaching. Harrison and Rainer (1992) assure that teachers with weak attitudes towards ICT often display low competencies in using computers. They would be, therefore, less likely to use ICT in their teaching and learning.

Likewise, attitudes of school leaders also play a critical role in determining the level of ICT integration in school (BECTA, 2007; Walsh, 2002; Pelgrum, 1993). In fact, it has been considered that "schools, whose principals have positive expectations regarding the educational impact of computers, tend to emphasize computer integrated learning more than schools with principals who are less positive” (Pelgrum: p. 209). In fact, principals with positive attitudes and strong commitment to ICT (Walsh, 2002) tend to be more able to influence teachers to use ICT in schools (Becta, 2007).

In fact, if it is true that: "principals can develop their own qualities in others" (Gurr et al., 2006: p.12), then the argument that teachers' attitudes are derivatives of school principals should be accepted. For this reason, in this paper, attitudes of school principals are investigated in relation to their leadership styles assuming that both have a strong influence on teachers' attitudes and hence the degree to which they foster the integration of ICT in their teaching.

\section{Context and Methodology}

There are 1281 schools in Lebanon (D-RASATI, 2011) managed by the Lebanese Ministry of Education and Higher Education. The overall number of public schools with trained ICT teachers is almost $57 \%$ of all public schools (D-RASATI, 2011). Although these figures are not quite high, they should not constitute an excuse against using ICT in these schools minimally.

In the context of this study, 1261 schools were addressed (20 schools were used for piloting purposes) and only 651 schools responded. In fact, three questionnaires were mailed to schools: two to be filled by the school principal and a third to be filled by one teacher from the participating school. The selection of this teacher was left for the school principal. In fact, principals were requested to administer the questionnaire to the teacher in their school that they thought was mostly active in using ICT in his/her teaching. 
School principals' questionnaires included a Leadership Style Survey designed by University of Exeter, UK in 2002. This questionnaire was piloted in an earlier study in Lebanon (Akoum, 2010) where 20 school principals administered this questionnaire. These principals are not part of the current study. The second questionnaire administered to school principals included "Attitudes towards ICT Scale' developed by Albirini" (2006). In this study, this survey was subjected to minor amend ments and was piloted by 10 public school principals that are not part of this study. Teachers' questionnaire included Isleem’s (2003) “Technology Level of Use”. Both Albirini (2006) and Isleem (2003) have been scrutinized in light of the findings of Ghamrawi (2010) study addressing ICT in education within the same cultural context.

\section{Analysis of Data}

Data were processed using Statistical Package for Social Science-SPSS 17.0; and the following steps were followed to carry out data analysis:

1) The descriptive statistics was used in summing the data including frequency percentages, means, and standard deviations.

2) Pearson's correlation coefficients were used to identify the relationships between the level of ICT use and attitudes of school principals towards ICT.

\section{Question (1): What Are the Leadership Styles That Prevail in Lebanese Public Schools?}

Principals $(\mathrm{N}=651)$ responded to Leadership Styles questionnaire. The instrument contains 30 statements about leadership style beliefs with a Likert scale format consisting of 5 points: 1 = almost never true, 2 = seldom true, 3 = occasionally true, 4 = frequently true, 5 = almost always true.

The results of descriptive data analysis reveal (Figure 3) that the autocratic style is the most prevailing leadership style in Lebanese Public Schools with a mean $\mathrm{M}=36.18$ and a standard deviation SD $=3.643$. The second most pervasive style is the democratic leadership style with a mean $\mathrm{M}=25.78$ and a standard deviation SD $=3.643$. The least invasive style is the delegative leadership style with a mean $\mathrm{M}=17.11$ and standard deviation $\mathrm{SD}=2.549$.

\section{Question (2): What Are the Attitudes among Principals towards the Use of ICT for Educational Purposes?}

Principals $(\mathrm{N}=651)$ responded to a customized version of “Attitude towards ICT Use' questionnaire developed by the Albirini (2006). The instrument contains 15 statements about attitudes towards using ICT in education with a Likert scale format consisting of 5 points: 1 = strongly disagree to the concept, 2 = disagree to the concept, $3=$ undecided to the concept, $4=$ agree to the concept, and $5=$ strongly favorable to the concept. Results are presented in Table 2. For the analysis of the data, all negatively worded items were reversed so that a higher numbered response on the Likert scale would represent positive attitudes.

On the positive side: 1) $72.2 \%$ of principals considered computers "help them organize the work' (mean score $\mathrm{M}=3.76$ standard deviation $\mathrm{SD}=1.27$ ); 2) $65.6 \%$ of school principals
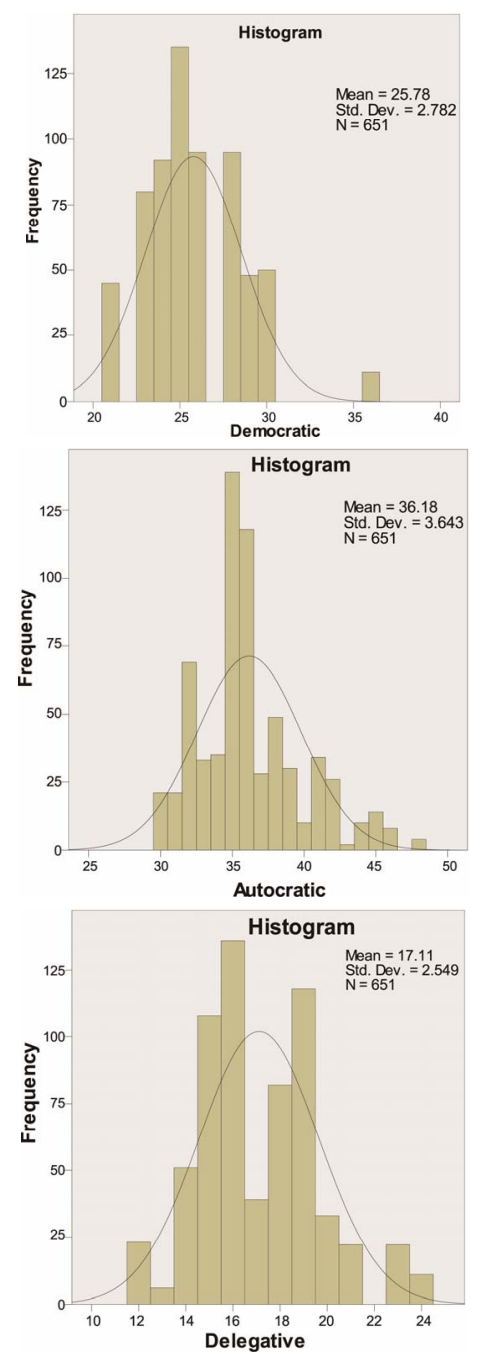

Figure 3.

Histograms representing data derived from leadership styles questionnaire.

considered computers as effective tools for "retrieving information” (mean score $\mathrm{M}=3.70$-standard deviation $\mathrm{SD}=1.38$ ); and 3) $67.8 \%$ of principals considered computers to be "time and effort saviors" (mean score $\mathrm{M}=3.65$-standard deviation SD = 1.37). However, on the negative side: 1) $63 \%$ of school principals did not view any "advantage" for using computers in teaching (mean score $\mathrm{M}=3.63$-standard deviation $\mathrm{SD}=1.26$ ); 2) $63.10 \%$ of school principals did not make see any relationship between the use of computers in education and "improvement of education" and (mean score $\mathrm{M}=3.40$-standard deviation $\mathrm{SD}=1.40$ ); 3 ) $37.2 \%$ of principals did not view computers as "enhancers of student learning" (mean score $\mathrm{M}=3.70$ standard deviation SD = 1.38); 4) $39.1 \%$ of principals did not make any connotation between "computers and increased student interest"(mean score $\mathrm{M}=2.79$-standard deviation SD = 1.50); and 5) $41.9 \%$ of principals preferred being "manual rather than digital" (mean score $\mathrm{M}=2.80$-standard deviation $\mathrm{SD}=1.48)$.

The overall average for the Means of principals' attitudes towards the use of computers was $\mathrm{M}=3.19$ with a standard deviation of $\mathrm{SD}=1.43$. This entails that school principals do bear 
Table 2.

Means, STD. deviations and percentages of teachers' attitudes.

\begin{tabular}{|c|c|c|c|c|c|c|c|}
\hline \multirow{2}{*}{ Statements } & \multicolumn{5}{|c|}{ Percentage \% } & \multirow{2}{*}{$\mathbf{M}$} & \multirow{2}{*}{ SD } \\
\hline & SD & D & UN & A & SA & & \\
\hline Computers would help me organize my work & 9.9 & 9.2 & 8.6 & 38.7 & 33.5 & 3.76 & 1.27 \\
\hline Using computer would make subject matter more interesting & 28.6 & 20.9 & 11.4 & 20.4 & 18.7 & 2.79 & 1.50 \\
\hline Computers save time and effort & 12.3 & 11.6 & 8.4 & 33.8 & 34.0 & 3.65 & 1.37 \\
\hline Using computers is enjoyable & 18.1 & 17.4 & 11.0 & 31.0 & 22.6 & 3.22 & 1.43 \\
\hline Computers make me much more productive & 23.2 & 17.8 & 12.9 & 29.0 & 17.0 & 2.98 & 1.44 \\
\hline Teaching with computers do not offer real advantages & 9.0 & 11.2 & 16.8 & 32.9 & 30.1 & 3.63 & 1.26 \\
\hline Computers have proved to be effective learning tools & 24.7 & 16.3 & 13.3 & 29.2 & 16.3 & 2.96 & 1.44 \\
\hline Computers can enhance students’ learning & 28.2 & 24.9 & 9.70 & 24.7 & 12.5 & 2.68 & 1.42 \\
\hline I would rather do things by hand than with a computer & 28.0 & 21.3 & 8.80 & 26.0 & 15.9 & 2.80 & 1.48 \\
\hline Computers will not necessarily improve education & 16.6 & 13.1 & 7.3 & 39.4 & 23.7 & 3.40 & 1.40 \\
\hline Computers do not scare me at all & 24.3 & 19.4 & 11.6 & 27.7 & 17.0 & 2.93 & 1.45 \\
\hline I do not like talking with others about computers & 24.9 & 18.3 & 10.1 & 24.1 & 22.6 & 3.01 & 1.52 \\
\hline I believe that using computers in teaching is useful & 21.7 & 24.5 & 12.5 & 20.9 & 20.4 & 2.93 & 1.46 \\
\hline Computers are a fast means of getting information & 14.0 & 8.8 & 11.6 & 31.4 & 34.2 & 3.70 & 1.38 \\
\hline I would like to learn more about computers & 26.5 & 8.0 & 6.0 & 32.3 & 32.3 & 3.26 & 1.57 \\
\hline Overall & 20.3 & 16.2 & 9.5 & 30.6 & 23.4 & 3.19 & 1.43 \\
\hline
\end{tabular}

positive attitudes towards computers but not towards considering them as promising tools to improve teaching and learning.

\section{Question (3): What Is the Level of ICT Use for Educational Purposes by Teachers'?}

Teachers $(\mathrm{N}=651)$ responded to the "Level of Use of ICT" questionnaire developed by Isleem (2003). The instrument contains 13 statements about the use of ICT by teachers with a Likert scale format consisting of 5 points: $1=$ never use, $2=$ rarely use, 3 = sometimes use, 4 = often use, 5 = very often use. Results are presented in Table 3.

On the positive side: 1) $51.8 \%$ stated that they used the internet (mean score $\mathrm{M}=3.34$-standard deviation $\mathrm{SD}=1.34$ ); 2 ) $49.9 \%$ of teachers explained that they used CDs (mean score M = 3.14-standard deviation SD = 1.46); 3) $47.3 \%$ of teachers used PowerPoint (mean score $\mathrm{M}=3.12$-standard deviation SD = 1.43); and 4) $26.4 \%$ used word processing (mean score $\mathrm{M}=$ 2.55-standard deviation $\mathrm{SD}=1.25$ ).

However, the lowest percentages obtained for computer use were given to: 1$)$ simulations and games ( $46.7 \%$ with a mean score $\mathrm{M}=2.03$ and standard deviation $\mathrm{SD}=0.87$ ); 2) emails (40\% with a mean score $\mathrm{M}=2.45$ and standard deviation $\mathrm{SD}=$ $1.14)$; 3 ) authoring (39.1\% with a mean score $M=2.16$ and standard deviation $\mathrm{SD}=1.00)$; and 4 ) spreadsheets programs (37.6\% with a mean score $\mathrm{M}=2.09$ and standard deviation SD $=1.14)$.

Overall, $28.6 \%$ of the total sample of teachers reported that they never used the ICT tools for educational purposes, and $26.3 \%$ stated that they rarely used ICT tools for the same purpose, while $25.1 \%$ from the total number of teachers reported that they often and very often used ICT for educational purposes. The overall average of the Mean scores of the use of ICT tools for educational purposes by teachers was $(\mathrm{M}=2.52)$ with a standard deviation $(\mathrm{SD}=1.19)$. Thus the level of use of ICT by teachers for educational purposes was low.

\section{Question (4): Is There a Significant Relationship between Level of Use of ICT and Principals' Attitudes towards ICT?}

Pearson's correlation coefficient was calculated to investigate any correlation between principals' attitudes towards ICT use versus the level of its use by their teachers in schools. Results which are presented in Table 4 indicate that a positive correlation does exist between the two $(r=0.50 ; p<.05)$.

Question (5): Is There a Significant Relationship between the Leadership Styles of School Principals in the Lebanese Public Schools and the Attitudes of Those Principals towards the Use of ICT for Educational Purposes?

The Pearson product moment correlation coefficient was used to determine the strength and direction of the relationship between leadership styles and the attitudes of principals towards the use of ICT for educational purposes. Results are presented in Tables 5-7 indicating that there is a positive correlation between the autocratic leadership style exhibited by the majority of school principals included in this study, as opposed to their attitudes towards the use of ICT for educational purposes $(r=.701, p<.01)$. However, weak positive correlation has been noted between democratic leadership style $(r=.452, p$ $<0.01)$ and delegative leadership style $(r=.421, p<.01)$.

\section{Summary of Findings and Discussion}

This study has shown that autocratic leadership is the most prevailing leadership style in the Lebanese Public Schools. Within the Lebanese Educational System, school principals are 


\section{N. GHAMRAWI}

Table 3.

Means, std. deviations and percentages of level of use of ICT.

\begin{tabular}{|c|c|c|c|c|c|c|c|}
\hline \multirow{2}{*}{ Statements } & \multicolumn{5}{|c|}{ Percentage \% } & \multirow{2}{*}{$\mathbf{M}$} & \multirow{2}{*}{ SD } \\
\hline & Never & Rarely & Sometimes & Often & Very Often & & \\
\hline Computer & 18.5 & 41.1 & 17.0 & 18.5 & 4.9 & 2.50 & 1.13 \\
\hline Spreadsheet program (such as Excel) & 37.6 & 33.3 & 16.8 & 6.5 & 5.8 & 2.09 & 1.14 \\
\hline Drill and Practice & 29.0 & 36.8 & 16.6 & 12.7 & 4.9 & 2.27 & 1.15 \\
\hline Graphics & 26.7 & 3.50 & 20.4 & 13.1 & 4.3 & 2.32 & 1.13 \\
\hline Word Process (such as Word) & 24.7 & 29.7 & 19.1 & 18.7 & 7.7 & 2.55 & 1.25 \\
\hline Desktop publishing (such as Microsoft Publisher) & 25.4 & 33.3 & 16.3 & 14.0 & 11.0 & 2.51 & 1.30 \\
\hline Authoring (such as html) & 39.1 & 28.6 & 20.4 & 10.3 & 1.5 & 2.16 & 1.00 \\
\hline CD-ROM, DVD & 20.9 & 16.3 & 12.9 & 27.5 & 22.4 & 3.14 & 1.46 \\
\hline E-Mail & 40.0 & 20.4 & 18.5 & 15.5 & 5.6 & 2.45 & 1.14 \\
\hline Other communication & 32.3 & 34.0 & 17.8 & 9.5 & 6.5 & 2.23 & 1.18 \\
\hline Simulations and games & 46.7 & 28.2 & 19.4 & 4.7 & 1.1 & 2.03 & 0.87 \\
\hline Presentation (such as PowerPoint) & 19.1 & 18.1 & 15.5 & 25.6 & 21.7 & 3.12 & 1.43 \\
\hline Internet & 11.8 & 18.1 & 18.3 & 27.1 & 24.7 & 3.34 & 1.34 \\
\hline Overall & 28.6 & 26.3 & 17.6 & 15.7 & 9.4 & 2.52 & 1.19 \\
\hline
\end{tabular}

Table 4.

Pearson correlation coefficient for the attitudes of school principals towards ICT versus the level of use of it by their teachers in their schools.

\begin{tabular}{cccc}
\hline & & $\begin{array}{c}\text { ICT Use by } \\
\text { Teachers }\end{array}$ & $\begin{array}{c}\text { Attitudes of } \\
\text { Principals }\end{array}$ \\
\hline ICT Use by Teachers & $\mathrm{R}$ & 1.00 & \\
& Sig. & & 1.00 \\
Attitudes of Principals & $\mathrm{R}$ & $.499^{* *}$ & \\
\hline
\end{tabular}

Note: ${ }^{* *} p<.01$.

Table 5.

Pearson correlation coefficient for the autocratic leadership style and the attitudes of school principals towards ICT use for educational purposes.

\begin{tabular}{cccc}
\hline & & $\begin{array}{c}\text { ICT Use by } \\
\text { Teachers }\end{array}$ & $\begin{array}{c}\text { Attitudes of } \\
\text { Principals }\end{array}$ \\
\hline ICT Use by Teachers & $\mathrm{R}$ & 1.00 & $.701^{* *}$ \\
& Sig. & & .000 \\
Attitudes of Principals & $\mathrm{R}$ & $.701^{* *}$ & 1.00 \\
& Sig. & .000 & \\
\hline
\end{tabular}

Note: ${ }^{* *} p<.01$.

dictated as to what they should be doing in their schools by the General Directorate of Education at MEHE. Only superficial and day-to-day decisions are left for them inside their schools (Yacoub, 2000). Within that context, school principals themselves do not have a say in decisions pertaining to their schools. They would be expected to practice the same thing over their teachers; generating orders rather than inviting them to take a share in school decisions. It seems, the same way tasks are dictated to those principals, such principals also dictate tasks to their staff. At the policy level, this is quite an alarming finding. If we wish to witness democratic practice in schools, then such democracy need to be modeled by higher authorities as well.
Table 6.

Pearson correlation coefficient for the democratic leadership style and the attitudes of school principals towards ICT use for educational purposes.

\begin{tabular}{cccc}
\hline & & $\begin{array}{c}\text { ICT Use by } \\
\text { Teachers }\end{array}$ & $\begin{array}{c}\text { Attitudes of } \\
\text { Principals }\end{array}$ \\
\hline ICT Use by Teachers & $\mathrm{R}$ & 1.00 & $.452^{* *}$ \\
& Sig. & & .000 \\
Attitudes of Principals & $\mathrm{R}$ & $.452^{* *}$ & 1.00 \\
& Sig. & .000 & \\
\hline
\end{tabular}

Note: ${ }^{* *} p<.01$.

Table 7.

Pearson correlation coefficient for the delegative leadership style and the attitudes of school principals towards ICT use for educational purposes.

\begin{tabular}{cccc}
\hline & & $\begin{array}{c}\text { ICT Use by } \\
\text { Teachers }\end{array}$ & $\begin{array}{c}\text { Attitudes of } \\
\text { Principals }\end{array}$ \\
\hline ICT Use by Teachers & $\mathrm{R}$ & 1.00 & $.421^{* *}$ \\
& Sig. & & .000 \\
Attitudes of Principals & $\mathrm{R}$ & $.421^{* *}$ & 1.00 \\
& Sig. & .000 & \\
\hline
\end{tabular}

Note: ${ }^{* *} p<.01$.

At the same time, and on one hand; the study has shown that though the principals of these schools bear positive attitudes towards computers; they did not consider them as important tools for the enhancement of teaching and learning. They valued computers as tools for the facilitation of the management of information in their schools and for administrative purposes mainly. This is probably what they have been exposed to. With training that focuses on the benefits students could earn out of ICT use in classrooms, more advocates of educational technology can be generated from the population of school principals.

On the other hand, the study has revealed a low level of use 
of ICT by teachers in those schools. A palpable correlation existed between the attitudes of school principals towards ICT and the level of its use by their teachers in classrooms. This could be attributed to several factors such as the fact that if school principals do not appreciate ICT, then they would not tend to encourage it in the school. When this is the case, teachers who are under the authority of those school principals would get discouraged to use it. However, future research needs to address this particular relationship.

The literature has emphasized the critical role school leaders played in the nourishment and enhancement of ICT use in their schools (Kearney \& McGarr, 2009; Kirkland \& Sutch, 2009; Haynes, 2007; Steed et al., 2005; Jacobson \& Hunter, 2004; Schiller, 2003; Solwinski, 2000). This study is aligned with those findings. It has proven that there is a positive correlation between the autocratic leadership style practiced by the majority of school principals included in this study and their attitudes towards ICT. Further qualitative research should investigate why autocratic leaders possessed negative attitudes towards ICT. Figure 4 summarizes the findings of this study.

\section{Conclusion and Recommendations}

This study suggests that leadership development in school principals should not be neglected prior to any ICT reform initiative in schools. Autocratic leadership styles seem to hinder ICT integration in teaching and learning. There has been a statistically significant relationship existing between autocratic leadership styles and negative attitudes towards using ICT in teaching and learning. Though further analysis is needed to assure the positive impact of democratic leadership styles; principals' training should address the promotion of more developmental leadership styles, where concepts such as shared decision making, distributed leadership and professional learning would dominate. Autocratic leadership style works best when the leaders possess all the information and skills to handle a given issue (Goleman, 2000). Given the fact the competency of public school principals in Lebanon is not advanced, then such a leadership style, which dominates schools as the study suggests, cannot serve the purpose of ICT integration in schools.
This study also suggests that the behavior of the leader affects the motivation mechanisms of teachers which in itself impede or catalyze ICT integration in teaching and learning. It is important to impact the attitudes of school principals and hence render them more positive towards ICT. This is another element that needs to be part of training initiatives of Public School principals in Lebanon. Impacting principals' attitudes positively is expected to motivate teachers to amalgamate ICTs in their teaching and learning. Further qualitative research should address this relationship to gain deeper understanding of this relationship. The hypothesis is that with more democratic leadership styles, attitudes of teachers would be more positively enhanced and hence more chances for ICT reform initiatives will be made available.

Finally, technology accompanies students throughout their day except at school (Ghamrawi, 2010). With the escalation of the use of technology by students in their daily-lives its integration in teaching and learning becomes more and more important (Ghamrawi, 2010). Giving it a blind eye is just like solving problems via “Ostrich Techniques”. Technology is expanding more and more and thorough planning and training need to be secured in that line. This study has contributed to the existing body of research regarding the integration of ICT for educational purposes. It is of special value to Lebanese Public Education Sector as no similar studies have been conducted. Yet it is also valuable to all policy makers and stakeholders worldwide.

As stated earlier, future qualitative studies are recommended such as classroom observations and in-depth interviews to investigate details of the trio relationship addressed in this study.

\section{Limitations of the Study and Future Research}

The sample for the present study comprised almost 50\% of the total population of public school principals in Lebanon, yet only 651 teachers out of the total population of teachers that represent nothing more than $5 \%$ of that population. Therefore, research studies with much larger sample size would be favored to ensure appropriate generalization of the findings of the study.

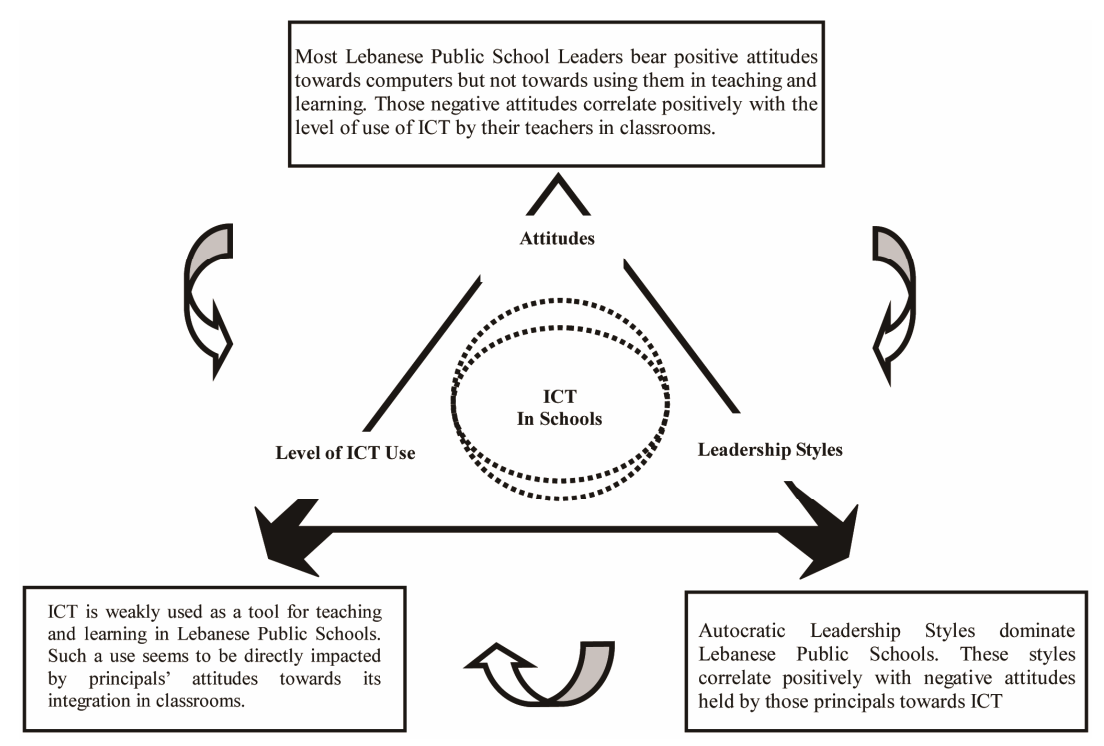

Figure 4.

Summary of findings of the study. 
The construct of the research instrument has been developed by the researcher based on findings of another study conducted by this same researcher in the same cultural context in which the current study was conducted. Though the instrument shows scientific reliability and validity, it would be advisable for other researchers to evaluate the instrument before use in other settings.

The present study has relied largely on quantitative methodology of data collection and is therefore restrictive. A more of qualitative methodology of data collection should be undertaken in future to provide wider perspective to the present study. For instance, the research design can employ case study methodology or content analysis to provide a holistic picture to the given subject.

Based on the previous discussion, future research should approach the same topic, however, qualitatively so that a deeper empathetic understanding of the inhibiters of ICT integration in teaching and learning can be depicted. This is besides earning plural understanding of leadership styles play a role in that line. In addition, analyzing results in light of demographic characteristics would be also an added value to the literature as age, gender, experience; previous training, etc. could play underestimated roles in this same line.

\section{Acknowledgements}

Special thanks are dedicated to the Lebanese University for supporting this research study.

\section{REFERENCES}

Akoum, N. (2010). Factors motivating teachers in Lebanese Public Schools. Unpublished M.S. Thesis, Beirut: Lebanese University.

Albirini, A. A. (2006). Teacher's attitudes toward information and communication technologies: The case of Syrian EFL teachers. Journal of Computers and Education, 47, 373-398.

doi:10.1016/j.compedu.2004.10.013

Anderson, R. E., \& Dexter, S. L. (2000). School technology leadership: Incidence and impact. Centre for Research on Information Technology and Organizations. Irvine, CA: University of California. http://www.crito.uci.edu/tlc/findings/report_6/report_6.pdf

Bennis, W., \& Nanus, B. (1985). Leaders: The strategies for taking charge. New York: Harper \& Row.

BECTA (2007). The impact of ICT in schools: A landscape review. Coventry: BECTA.

http://www.pedagogy.ir/images/pdf/impact_ict_schools.pdf

BECTA (2003). Primary schools: ICT and standards. http://www.becta.org.uk

Bransford, J., Brown A. L., \& Cocking, R. R. (2000). How people learn: Brain, mind, experience and school (2nd ed.). Washington DC: National Academy Press.

Coates, D., Humphreys, B. R. et al. (2004). No significant distance between face-to-face and online instruction: Evidence from principles of economics. Economics of Education Review, 23, 533-546. doi:10.1016/j.econedurev.2004.02.002

Condie, R., \& Munro, R. (2007). The impact of ICT in schools: A landscape review. Strathclyde: University of Strathclyde.

Day, C. (2003). What successful leadership in schools looks like: Implications for policy and practice (pp. 187-204). In B. Davies, \& J. West-Burnham (Eds.), Handbook of educational leadership and management. Edinburgh Gate: Pearson Education Limited

Day et al. (2010). 10 strong claims about effective school leadership. Nottingham: National College for Leadership of Schools and Children's Services.

Developing Rehabilitation Assistance to Schools and Teacher Improvement (D-RASATI) (2011). Field Survey Results Report of Lebanese
Public Schools. Beirut: Lebanese Ministry of Education and Higher Education.

Dubrin, A. J., Dalglish, C., \& Miller, P. (2006). Leadership. Milton: John Wiley \& Sons, Ltd.

Fuchs, T., \& Woessmann, L. (2004). Computers and Student Learning: Bivariate and Multivariate Evidence on the Availability and Use of Computers at Home and at School, CESifo Working Paper. No. 1321. Munich: CESifo.

Flanagan, L., \& Jacobsen, M. (2003). Technology leadership for the 21st century principal. Journal of Educational Administration, 41, 124-142. doi:10.1108/09578230310464648

Fullan, M. (2005). Leadership and sustainability: Systems thinkers in action. California: Corwen Press and Ontario Principals' Council.

Fullan, M. (2002). Principals as leaders in a culture of change, educational leadership. http://www.michaelfullan.ca/Articles_02/03_02.htm

Ghamrawi, N. (2010). Teaching-learning-technology (TLT): A new formula for school enhancement. International Journal of Excellence in Education, 3. http://journals.hbmeu.ae/

Gillespie, H. (2006). Unlocking learning and teaching with ICT: Identifying and overcoming barriers. London: David Fulton.

Glennan, T. K., \& Melmed, A. (1995). Fostering the use of educational technology: Elements of a national strategy. Washington DC: RAND. http://www.rand.org/publications/MR/ MR682

Goleman, D. (2004). What makes a leader? Harvard Business Review, 82, 82-91.

Goleman, D. (2000). Leadership that gets results. Harvard Business Review, 78, 78-90.

Grimus, M. (2000). ICT and multimedia in the primary school. The 16th Conference on Educational Uses of Information and Communication Technologies, Beijing, 21-25 August.

Gurr, D., Drysdale, L., \& Mulford, B. (2006). Models of successful principal leadership. School Leadership and Management, 26, 371395. doi:10.1080/13632430600886921

Harris, A. (2003). Teacher leadership: A new orthodoxy? In B. Davies, \& J. West-Burnham (Eds.), Handbook of educational leadership and management (pp. 44-50). Edinburgh Gate: Pearson Education Limited.

Harrison, W., \& Rainer, K. (1992). An examination of the factor structures and concurrent validates for the computer attitude scale, the computer anxiety rating scale, and the computer self-efficacy scale. Educational and Psychological Measurement, 52, 735-744. doi:10.1177/0013164492052003024

Hayes, D. N. A. (2007). ICT and learning: Lessons from Australian classrooms. Computers \& Education, 49, 385-395. doi:10.1016/j.compedu.2005.09.003

Hsieh-Yee, I. (2000). Organizing internet resources: Teaching cataloging standards and beyond. OCLC Systems \& Services, 16, 130-143. doi:10.1108/10650750010345256

Jacobson, M., \& Hunter, W. (2004) Leadership and technology in schools. http://www.ucalgary.ca/ iejll/volume7/leadershipandtechnologyedito rial.htm

Jonassen, D., \& Reeves, T. (1996). Learning with technology: Using computers as cognitive tools. In D. Jonassen (Ed.), Handbook of research educational on educational communications and technology (pp. 693-719). New York: Macmillan.

Kay, K., \& Honey, M. (2009). Beyond technology competency: A vision of ICT literacy to prepare students for the 21st century. Charleston, WV: Evantia.

Katz, R. N. (2002). The ICT infrastructure: A driver of change. Educause, July-August 2002, 50-61.

Kearney, G., \& McGarr, O. (2009). The role of the teaching principal in promoting ICT use in small primary schools in Ireland. Technology, Pedagogy and Education, 18, 87-102. doi:10.1080/14759390802704139

Kluever, C., Lam, T., \& Hoffman, R. (1994). The computer attitude scale: Assessing changes in teachers' attitudes toward computers. Journal of Educational Computing Research, 11, 251-256. doi:10.2190/484T-CPGX-EUHG-QW8P

Kirkland, K., \& Sutch, D. (2009). Overcoming the barriers to educa- 


\section{N. GHAMRAWI}

tional innovation. Bristol: Futurelab.

Kozma, R. (2003). Technology, innovation and educational change: A global perspective. Oregon: Eugene:

Kulik, J. A. (1994). Meta-analysis study of findings on computer-based instruction. In E. L. Baker, \& H. F. O’neil (Eds.), Technology assessment in education and training. Hillsdale, NJ: Lawrence Erlbaum.

Law, N., Chow, Y., \& Yuen, H. K. (2005). Methodological approaches to comparing pedagogical innovations using technology. Education and Information Technologies, 38, 7-20. doi:10.1007/s10639-005-6744-7

Lee, M., Gaffney, M., \& Schiller, J. (2001). Integrating ICT in your school: New opportunities for leadership. Los Angeles: Sage Publications

Leuven, E., Lindahl, M., Oosterbeek, H., \& Webbink, D. (2004). The effect of extra funding for disadvantaged pupils on achievement. IZA Discussion Paper. No. 1122. Bonn: Institute for the Study of Labor.

MacDonald, R. (2006). Factors contributing to teacher information communication technology integration. Belmont, CA: Wadsworth.

McCausland, H., Wache, D., \& Berk, M. (1999). Computer literacy; its implications and outcomes: A case study from the Flexible Learning Centre. Adelaide: University of South Australia.

Moore, M., \& Kearsley, G. (1996). Distance education: A systems view. Belmont, CA: Wadsworth.

Murphy, C. (2006). The impact of ICT on primary science. In P. Warwick, E. Wilson, \& M. Winterbottom (Eds.), Teaching and learning primary science with ICT (pp. 13-32). Berkshire: Open University Press

OECD (2001). Schooling for tomorrow learning to change: ICT in schools. Paris: OECD.

Ofsted (2000). Improving city schools. London: Office for Standards in Education.

Oliver, R. (2000). Creating meaningful contexts for learning in webbased settings. Proceedings of Open Learning 2000, Brisbane: Learning Network, 53-62.

Pelgrum, W. J. (1993). Attitudes of school principals and teachers towards computers: Does it matter what they think? Studies in Educational Evaluation, 19, 199-212. doi:10.1016/0191-491X(93)90007-E

Postman, N. (1995) The end of education. New York: Alfred A. Knopf.

Romeo, G. I. (2006). Engage, empower, enable: Developing a shared vision for technology in education. In M. S. Khine (Ed.), Engaged learning and emerging technologies. Amsterdam: Springer Science. doi:10.1007/1-4020-3669-8 8
Schiller J. (2002). Interventions by school leaders in effective implementation of information communication technologies: Perceptions of Australian principal. Journal of Information Technology for Teacher Education, 11, 12-35. doi:10.1080/14759390200200138

Schiller, J. (2003) The elementary school principal as a change facilitator in ICT integration.

http://technologysource.org/article/elementary_school_principal_as_ a change facilitator_in_ict_integration.pdf

Schoeny, Z. G. (2002) Leadership of information technology in education. Journal of Information Technology for Teacher Education, 11, 84-102.

Slowinski, J. (2000). Becoming a technology savvy administrator. http://eric.uoregon.edu/publications/digests/digest135.html

Sosin, K., Blecha, B. J., Agawal, R., Bartlett, R. I., \& Daniel, J. I. (2004). Efficiency in the use of technology in economic education: Some preliminary results. American Economic Review, 34, 253-258. doi:10.1257/0002828041301623

Spillane, J. P. (2009). Managing to lead: Reframing school leadership and management. Kappan, 37, 70-73.

Steed, Hollingsworth, \& Marzek (2005). Leadership and ICT. http://www.uleth.ca/edu/faculty/members/steed/Articles/Scaling_Dig ital_Divide.pdf

Walsh, K. (2002). ICT's about learning: School leadership and the effective integration of information and communications technology. Nottingham: National College for School Leadership. http://forms.ncsl.org.uk/mediastore/image2/walsh-ict-full.pdf

Wong, A. F. L., Quek, C. L., Divaharan, S., Liu, W. C., Peer, J., \& Williaams, M. D. (2206). Singapore students' and teachers' perceptions of computer-supported project work classroom learning environments. Journal of Research in Technology in Education, 38, 449-479.

Yee, D. (2001). The many faces of ICT leadership. In B. Barrell (Ed.), Technology, teaching and learning: Issues in the integration of technology (pp. 223-238). Calgary, AB: Detselig.

Yelland, N. (2001). Teaching and learning with information communication technology (ICT) for numeracy in early childhood and primary years of schooling. Sydney: Department of Education, Training and Youth Affairs.

Yacoub, S. (2000). School principalship in Lebanon: Problems and suggested solutions. Lebanese Association for Educational Studies, 1, 295-330.

Young, J. (2002). The 24-hour professor. The Chronicle of Higher Education, 48, 31-33. 